\title{
Effect of Dietary Carbohydrate Levels and Feeding Frequencies on Growth and Carbohydrate Digestibility by White Shrimp Litopenaeus vannamei Under Laboratory Conditions
}

\author{
Zainuddin*, Haryati and Siti Aslamyah
}

Department of Fisheries, Faculty of Marine Science and Fisheries, Hasanuddin University, Sulawesi Selatan 90245, Indonesia

\begin{abstract}
This study aims to determine the level of carbohydrate and feeding frequency on the growth and the carbohydrate digestibility of juvenile shrimp vanamei. This study used a factorial design patterns completely randomized design with two factors and three replications of each factor given time. The treatments tested were factor $A$ (carbohydrate feeding different levels, namely 26,32,38, and 44\%) and factor B (feeding frequency 2 times, 4 times, and 6 times per day). Shrimp juvenile were used have an average individual weight of $0.3 \mathrm{~g}$. Feeding dose is $10 \%$ of the body weight and the feeding frequency adapted to the treatment. The results showed that combination treatment with carbohydrate levels by $38 \%$ and the feeding frequency 4 times a day are the best combination of treatments to the specific growth rate and digestibility of carbohydrates juvenile white shrimp.
\end{abstract}

Keywords: Level; Carbohydrates; Frequency; Feeding; Growth, Digestibility

\section{Introduction}

Shrimp is the one commodity that contributes significantly to the increase in local revenues in South Sulawesi. In 2006 South Sulawesi shrimp production reached 19414 tonnes and a decline into 16361.4 tonnes in 2007 [1]. Decreased production of tiger shrimp in recent time due to virus attacks WSSV causes the need for diversification of species that are more resistant to disease. Shrimp Litopenaeus vannamei vanamei is one type of penaeid shrimp that have endurance higher than the species of tiger shrimp against viral attack.

In a system of intensive shrimp farming in ponds vanamei, feed is one of the strategic components that determine the success of the business. Feed is a very large part of the operational costs in the cultivation of crustaceans [2]. At the event, almost $60-70 \%$ of total production costs for the purchase of feed $[3,4]$. But the last few years of cultivation of these commodities often fail. One of the factors that lead to failure in shrimp farming in Indonesia vanamei cultivation technology is the application that does not comply with the carrying capacity of the waters, the farming technologies among others including feeding technology [5]. The high organic matter derived from the feed that is not consumed and is derived from the metabolism, is one of the triggers declining water quality.

The success of shrimp farming vanamei among others determined by the quality of feed used. To produce optimal growth, feed with shrimp require a fairly high protein content. Optimal growth is achieved when vanamei shrimp shrimp feed with protein content of 40$50 \%$ [6]. However, the protein content is too high can lead to decreased water quality cultivation media, which comes from the feed that can not be consumed, faeces and feed protein metabolism. [7] suggested that the protein needs of the shrimp can be reduced if the energy needs can be met from other sources of non-protein, such as carbohydrates

Carbohydrates and lipids are important nutritional components in food shrimp [8]. Increasing the proportion of carbohydrates and not protein feed to meet energy needs can ultimately feed costs. The addition of vegetable protein to reduce the cost of feed has been widely studied [9-12]. In addition to required as an energy source, shrimp also need carbohydrates for synthesis of chitin. Used by shrimp chitin in the growth process to form and replace eksoskleton during the molting process.

Carbohydrates are a source of cheap energy, but the ability of aquatic organisms, including shrimp to utilize limited. This is due to lack of ability to digest and regulate plasma glucose concentrations. The use of carbohydrate by fish and shrimp are less efficient than land animals [13]. The ability of shrimp in utilizing the limited carbohydrate digestibility due to low [14] and low concentrations of plasma glucose regulation [15]. The low digestibility of carbohydrates associated with the availability of the enzyme $\alpha$-amylase, whereas low concentrations of plasma glucose regulation allegedly caused by a deficiency of the hormone insulin. Based on the recommendation of the humans who suffer from diabetes, suggested that the feeding frequencyis much more then the ability to utilize carbohydrates can be improved. This is in line with research that the continuous feeding may increase the use of carbohydrates and increase fat reserves through increased lipogenesis process. In addition to the feeding frequencymore frequently, the possibility of higher feed can be consumed, so the rest of which will feed into the cultivation medium, which in turn will affect the water quality can be eliminated. Under these conditions, the purpose of this study was to determine the level of carbohydrate feed and feeding frequency on the growth rate and the best carbohydrate digestibility of juvenile shrimp vanamei.

*Corresponding author: Zainuddin, Department of Fisheries, Faculty of Marine Science and Fisheries, Hasanuddin University, Sulawesi Selatan 90245, Indonesia, Tel: 62411 586200; E-mail: zainuddin latif2013@yahoo.co.id

Received July 12, 2014; Accepted October 13, 2014; Published October 15 2014

Citation: Zainuddin, Haryati, Aslamyah S (2014) Effect of Dietary Carbohydrate Levels and Feeding Frequencies on Growth and Carbohydrate Digestibility by White Shrimp Litopenaeus vannamei Under Laboratory Conditions. J Aquac Res Development 5: 274 doi:10.4172/2155-9546.1000274

Copyright: ( 2014 Zainuddin, et al. This is an open-access article distributed unde the terms of the Creative Commons Attribution License, which permits unrestricted use, distribution, and reproduction in any medium, provided the original author and source are credited. 
Citation: Zainuddin, Haryati, Aslamyah S (2014) Effect of Dietary Carbohydrate Levels and Feeding Frequencies on Growth and Carbohydrate Digestibility by White Shrimp Litopenaeus vannamei Under Laboratory Conditions. J Aquac Res Development 5: 274 doi:10.4172/21559546.1000274

Page 2 of 4

\section{Materials and Methods}

\section{Experimental condition and animal}

The container used in this study is $60 \mathrm{~cm} \times 50 \mathrm{~cm} \times 50 \mathrm{~cm}$ sized glass aquarium with a total of 36 pieces each capacity 20 liters. The water used is sea water which has been diluted upto 20 ppt salinity.

Test animals used in this study were white shrimp juvenile (Litopenaeus vannamei) postlarva 25 local stadia. The prawns were taken from the nursery people in Maros. Shrimp is adapted to the type of artificial feed is tested. The stocking density of test animals used were 20 individual/container. Percentage of prescribed daily feeding as much as $10 \%$.

\section{Feed and husbandry}

Feed used in this study is the artificial feed composition has been determined and is shown in Tables 1 and 2. Especially for observation digestibility of dry matter in the feed chromium oxide added as much as $0.5 \%$.

In order to achieve the desired objectives of the research, white shrimp juvenile maintained for about two months At the time of maintenance, it is worth noting that the feeding frequency. The daily feeding frequency is performed twice a day, four times a day and six times per day according to the tested treatment. As for sampling weights and measurements performed once every week.

\section{The design of experiments}

The experimental design used in this study was a factorial design with completely randomized design basis. The first factor is the level of carbohydrates in the diet are: (A1) Carbohydrate content of feed by $44 \%$, (A2) Carbohydrate content of feed by $38 \%$, (A3) Carbohydrate content of feed by $32 \%$, (A4) Carbohydrate content of feed by $26 \%$.

Each level karbrohidrat given repeat 3 times. The second factor is the feeding frequency, respectively: (B1) feeding frequency of twice per day, (B2) feeding frequency of four times per day, (B3) feeding frequency of six times per day. Each treatment was given repetition

\begin{tabular}{|l|c|c|c|c|}
\hline \multirow{2}{*}{ Ingredient } & \multicolumn{4}{|c|}{ Diet $\mathbf{( g / 1 0 0 ~ g ~ a s - f e d ~ b a s i s ) ~}$} \\
\cline { 2 - 5 } & A1 & A2 & A3 & A4 \\
\hline Local fish meal & 5 & 16 & 27 & 35 \\
\hline Head shrimp meal & 10 & 10 & 10 & 10 \\
\hline Soybean meal & 30 & 27 & 25 & 30 \\
\hline Corn meal & 10 & 10 & 10 & 10 \\
\hline Bran meal & 24 & 24 & 19 & 11 \\
\hline Wheat meal & 17 & 9 & 5 & - \\
\hline Fish oil & 2 & 2 & 2 & 2 \\
\hline Vitamin mix & 1 & 1 & 1 & 1 \\
\hline Mineral mix & 1 & 1 & 1 & 1 \\
\hline Cromium oxide & 0.5 & 0.5 & 0.5 & 0.5 \\
\hline
\end{tabular}

Table 1: Ingredient composition of experimental diet.

\begin{tabular}{|l|c|c|c|c|}
\hline \multirow{2}{*}{} & \multicolumn{4}{|c|}{ \% Dry basis } \\
\cline { 2 - 5 } & A1 & A2 & A3 & A4 \\
\hline Crude protein & 30.09 & 35.88 & 41.56 & 49.71 \\
\hline Crude lipid & 6.42 & 6.73 & 6.61 & 8.37 \\
\hline Nitrogen-free extract & 49.65 & 40.41 & 32.68 & 18.44 \\
\hline Crude fiber & 5.14 & 4.93 & 4.48 & 6.68 \\
\hline Ash & 8.7 & 12.05 & 14.67 & 16.8 \\
\hline Gross energy (KKal/kg) & 4068.3 & 4016.1 & 3980.1 & 3976.4 \\
\hline
\end{tabular}

Table 2: Proximate analysis ( $g / 100$ dry $w t)$ of experimental diets used.

\begin{tabular}{|c|c|c|c|}
\hline \multirow{2}{*}{ Feed } & \multicolumn{3}{|c|}{ Feeding frequency } \\
\cline { 2 - 4 } & B1 & B2 & B3 \\
\hline A1 & $6.288 \pm 0.443^{\mathrm{b}}$ & $6.796 \pm 0.938^{\mathrm{b}}$ & $6.756 \pm 0.443^{\mathrm{b}}$ \\
\hline A2 & $7.198 \pm 1.294^{\mathrm{b}}$ & $9.888 \pm 0.083^{\mathrm{a}}$ & $6.494 \pm 0.615^{\mathrm{b}}$ \\
\hline A3 & $9.244 \pm 0.877^{\mathrm{a}}$ & $8.453 \pm 0.946^{\mathrm{a}}$ & $6.279 \pm 1.172^{\mathrm{b}}$ \\
\hline A4 & $6.363 \pm 0.721^{\mathrm{b}}$ & $6.082 \pm 0.498^{\mathrm{b}}$ & $6.594 \pm 0.705^{\mathrm{b}}$ \\
\hline
\end{tabular}

Note: different letters in the same row and column indicates treatment significantly different $(P<0.05)$

Table 3:.Daily specific growth rate (\%) of shrimp juvenile the combined treatment of feed carbohydrate levels and feeding frequency.

feeding frequency 3 times. Thus obtained 12 combined treatment replicates were each given 3 times to obtain 36 experimental units.

\section{Variables}

\section{Specific growth rate (SGR): $S G R=(\ln \mathrm{Wt}-\ln \mathrm{Wo}) / \mathrm{t} \times 100$}

Where: $\mathrm{Wt}=$ average individual weight at the final experiment $(\mathrm{g})$, $\mathrm{Wo}=$ average individual weight at the initial, experiment $(\mathrm{g}) \mathrm{t}=$ length of culture (days)

Carbohydrate digestibility: Carbohydrate digestibility will be calculated using the formula in Strickland and Parsons et al. [7] as follows:

Digestibility of dry matter $(\%)=\left(1-\% \mathrm{Cr}_{2} \mathrm{O}_{3}\right.$ in feed/\% $\mathrm{Cr}_{2} \mathrm{O}_{3}$ in feces $) \times 100$

Data analysis: Data were analyzed using analysis of variance. If the results of the analysis proved that significant treatment followed by Tukey's $\mathrm{W}$-test to determine the treatment that produced the best response.

\section{Results and Discussion}

\section{Specific Growth Rate (SGR)}

Specific growth rate of juvenile white shrimp A2B2 highest in the combination treatment, followed by $\mathrm{A} 3 \mathrm{~B} 1$ and $\mathrm{A} 3 \mathrm{~B} 2$ with values respectively $9.888 \pm 0.083 \%, 9.244 \pm 0.877$ and $8.453 \pm 0.946 \%$. All three treatment combinations were not significantly different $(\mathrm{P}>0.05)$ but significantly different from other treatment combinations $(\mathrm{P}<0.05)$ (Table 3).

The results showed that the specific growth rate of white shrimp juvenile daily highest achieved in the combined treatment $38 \%$ carbohydrate content of feed and feeding frequency of 4 times per day. This suggests that the juveniles were able to take advantage of white shrimp feed with feed carbohydrate content to $38 \%$ by increasing the feeding frequency of upto 4 times per day. Based on the recommendation of the humans who suffer from diabet, suggested that the feeding frequency is much more then the ability to utilize carbohydrates can be improved. This is in line with research that the continuous feeding may increase the use of carbohydrates and increase fat reserves through increased lipogenesis process. In addition to the feeding frequency more frequently, the possibility of higher feed can be consumed, so the rest of which will feed into the cultivation medium, which in turn will affect the water quality can be eliminated. Increased use of carbohydrates by shrimp is expected to increase levels of carbohydrate and reducing protein content in the composition of artificial feed. Growth performance and feed utilization efficiency is significantly influenced by the level of carbohydrate feed.

However, an increased feeding frequency up to 6 times per day instead give effect to the reduction in the rate of growth (Table 3 ). 
Citation: Zainuddin, Haryati, Aslamyah S (2014) Effect of Dietary Carbohydrate Levels and Feeding Frequencies on Growth and Carbohydrate Digestibility by White Shrimp Litopenaeus vannamei Under Laboratory Conditions. J Aquac Res Development 5: 274 doi:10.4172/21559546.1000274

Page 3 of 4

Although shrimp fed with high frequency by consuming large amounts of feed but narrow intervals of frequencies, then feed more quickly through the digestive tract and cause digestive ineffective [16] reported the feeding frequency 2 times per day with a span of 12 hours resulted in the best growth in Lates calcarifer juvenile feeding frequency compared to 3 and 4 times per day with a shorter time span. Based on this it can be explained that the maintenance of white shrimp juvenile feeding frequency 4 times a day is enough to improve growth performance.

\section{Carbohydrate digestibility}

The results showed that the combined treatment of carbohydrate level of feed and feeding frequency significantly $(<0.05)$ the digestibility of carbohydrates. Single factor of feed carbohydrate levels had no significant effect $(\mathrm{P}>0.05)$, but the frequency factor of feeding a significant effect $(\mathrm{P}<0.05)$ the digestibility of carbohydrates. Feeding frequency four and six times per day was not significantly different $(\mathrm{P}>0.05)$, but both were significantly different $(\mathrm{P}<0.05)$ with the feeding frequency two times a day (Table 4 and Figure 1).

Carbohydrates are a source of cheap energy, but the ability of aquatic organisms, including shrimp to utilize limited. This is due to lack of ability to digest and regulate plasma glucose concentrations. The low digestibility of carbohydrates associated with the availability of the enzyme $a$-amylase, whereas low concentrations of plasma glucose regulation allegedly caused by a deficiency of the hormone insulin. The results showed that the digestibility of carbohydrates by white shrimp juvenile increases with increasing feeding frequency. Despite this feeding frequency four and six times a day gives the same response. This is in line with research that the continuous feeding may increase the use of carbohydrates and increase fat reserves through increased lipogenesis process. In addition to the feeding frequency more frequently, the possibility of higher feed can be consumed, so the rest of which will feed into the cultivation medium, which in turn will affect the water quality can be elimination. It is seen from ammonia $-\mathrm{N}$ excretion were lower in the feeding frequency four times in this study.

\begin{tabular}{|c|c|c|c|}
\hline \multirow{2}{*}{ Feed } & \multicolumn{3}{|c|}{ Feeding frequency } \\
\cline { 2 - 4 } & B1 & B2 & B3 \\
\hline A1 & $86.26 \pm 0.728^{\mathrm{a}}$ & $87.95 \pm 0.560^{\mathrm{b}}$ & $88.89 \pm 0.475^{\mathrm{b}}$ \\
\hline A2 & $84.64 \pm 1.206^{\mathrm{a}}$ & $89.27 \pm 0.340^{\mathrm{b}}$ & $90.43 \pm 0.273^{\mathrm{b}}$ \\
\hline A3 & $84.79 \pm 0.371^{\mathrm{a}}$ & $88.99 \pm 0.696^{\mathrm{b}}$ & $90.77 \pm 0.431^{\mathrm{b}}$ \\
\hline A4 & $84.61 \pm 0.517^{\mathrm{a}}$ & $89.16 \pm 0.423^{\mathrm{b}}$ & $89.33 \pm 0.325^{\mathrm{b}}$ \\
\hline
\end{tabular}

Note: different letters in the same row indicate treatments significantly different $(P<0.05)$

Table 4: Carbohydrate digestibility (\%) of white shrimp juvenilein the combined treatment of feed carbohydrate levels and feeding frequency.

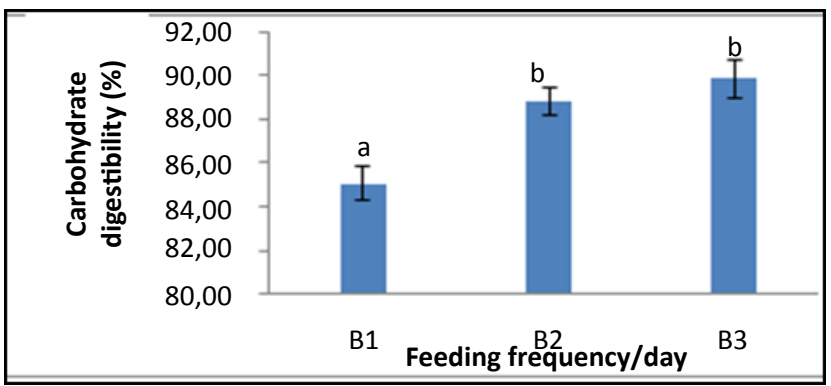

Figure 1: Graph digestibility of carbohydrates in the treatment of shrimp juvenile by feeding frequency per day.
The ability to use carbohydrates as an energy source varies between fish, shrimp, and terrestial animals. The use of carbohydrate by fish and shrimp are less efficient than terrestial animals [13]. The use of hot water in the manufacture of pellets was also influential, as it is known that carbohydrates are gelatinized, which increases the digestibility of shrimp [14-16]. The results showed that an increase in starch gelatinization for commercial feed manufacturing is expected to have a positive effect on digestibility [17]. Carbohydrates and lipids are important nutritional components in food shrimp [8]. From a practical standpoint, it is worth understanding how carbohydrates are used to provide information in design a better feed for the different growth phases of the shrimp.

The results of the study [17] showed that salinity variations do not affect the digestibility of carbohydrates and lipids by white shrimp juvenile on the container control. The quantity and quality of waste excreted by shrimp depends on consumption, digestion, and metabolism of the compound feed $[18,19]$ reported that the highest energy of feed consumed by white shrimp juvenile Litopenaeus vannamei was obtained when the salinity of the water is maintained at $26 \mathrm{ppt}$. White shrimp reared in low salinity shown to promote the growth and survival by adjusting the level of nutrients in the feed [20,21]. When the shrimp are exposed to low salinity, shrimp should resist the loss of $\mathrm{Na}+$ and $\mathrm{Cl}^{-}$by the active uptake of $\mathrm{Na}+$ from the water in exchange for $\mathrm{H}+$, which occurs in the apical membrane of the cell osmoregulatory to increase capacity osmoregulatory [22-24].

During the ongoing research of water quality parameter values remain at the limit eligibility for the growth and survival of white shrimp juvenile especially salinity was maintained in the range of 20 ppt. The values of physical parameters of the water quality is within acceptable limits for maintenance indoor shrimp production [10].

\section{Conclusion}

Based on the research that has been done can be concluded that the best level of carbohydrate feed was $38 \%$ with a feeding frequency four times a day. Level of $38 \%$ carbohydrate feed produces the highest specific growth rate and high carbohydrate digestibility.

\section{References}

1. Department of Fisheries and Marine Resources of South Sulawesi (2008) Annual Report of Fisheries Development Goals Realization and South Sulawesi. Department of Fisheries and Marine Resources of South Sulawesi province.

2. Cortés-Jacinto, Villarreal-Colmenares EH, Civera-Cerecedo R, MartínezCordova L (2003) Effect of dietary protein level on growth and survival of juvenil freshwater crayfish Cherax quadricarinatus (Decapoda: Parastacidae). Aquacult Nutr 9: 207-213.

3. Haryati, Saade E, Zainuddin (2009) Formulation and feed aplication for brustock and cultivation: Feed suplement aplication for the increase quality of tiger shrimp local brustock. University of Hasanuddin, Makassar.

4. Haliman RW, Dian AS (2005) White shrimp Litopenaeus vannamei: cultivation and market prospect of white shrimp disease resistence. Swadaya Press, Jakarta

5. Zainuddin, Abustang, Siti Aslamyah (2009) Probiotic utilization in commercial feed for cultivation of tiger shrimp. University of Hasanuddin, Makassar.

6. FAO (1987) Feed and feeding of fish and shrimp. A manual on the preparation and presentation of compound feeds for shrimp and fish aquaculture.

7. Koshio S, Teshima TS, Kanazawa A, Watase T (1993) The effect of dietary protein content on growth, digestion efficiency and nitrogen excretion of juvenil kuruma prawns, Penaeus japonicus Aquaculture 113: 101-114.

8. Gaxiola G, Cuzon G, Garcia T, Tabeada G, Brito R, et al. (2005) A factorial effects 
Citation: Zainuddin, Haryati, Aslamyah S (2014) Effect of Dietary Carbohydrate Levels and Feeding Frequencies on Growth and Carbohydrate Digestibility by White Shrimp Litopenaeus vannamei Under Laboratory Conditions. J Aquac Res Development 5: 274 doi:10.4172/21559546.1000274

of salinity, dietary carbohydrate and molt cycle on digestive carbohydrases and hexokinases in Litopenaeus vannamei (Boone, 1931). Comp Biochem Physiol 140: 29-39.

9. Cuzon G, Rosas C, Gaxiola G, Taboada G, Van Wormhoudt A (2000) Utilization of carbohydrates by shrimp

10. Campaña Torres A, Martinez Cordova LR, Villarreal Colmenares, CortésJacinto E (2010) Evaluation of different concentrations of adult live Artemia (Artemia franciscana, Kellogs 1906) as natural exogenous feed on the water quality and production parameters of Litopenaeus vannamei (Boone 1931) pregrown intensively. Aquacult Res 42: 40-46.

11. Radford CA, Marsden ID, Jeffs AG (2008) Specific dynamic action as an indicator of carbohydrate digestion in juvenil spiny lobsters, Jasus edwardsii. Mar Freshwat Res 59: 841-848.

12. Olmos J, Ochoa L, Paniagua-Michel J, Contreras R (2011) Functional feed assessment on Litopenaeus vannamei using $100 \%$ fish meal replacement by soybean meal, high levels of complex carbohydrates and Bacillus probiotic strains. Mar Drugs 9: 1119-1132.

13. Guo R, Liu YJ, Tian LX, Huang JW (2006) Effect of dietary cornstarch levels on growth performance, digestibility and microscopic structure in the white shrimp, Litopenaeus vannamei reared in brackish water. Aquacult Nutr 12: 83-88.

14. Mohapatra M, Sahu NP, Chaudhari A (2003) Utilization of gelatinized carbohydrates in diets of Labeoro hita fry. Aquacult Nutr 9: 189-196.

15. Shiau SY (1997) Utilization of carbohydrates in warmwater fish - with reference to tilapia, Oreochromis niloticus X O. aureus. Aquaculture 151: 79-96

16. Salama AJ (2008) Effects of different feeding frequency on the growth, survia and feed conversion ratio of the Asian sea bass Lates calcarifer juvenils reared under hypersaline seawater of the Red Sea. Aquacul Res 39: 561-567.

17. Thomas M, Van Vliet T, Van Der Poel AFB (1998) Physical quality of pelleted animal feed. Contribution of feed stuff components. Anim Feed Sci Techno 70: $59-78$

18. Amirkolaie AK (2011) Reduction in the environmental impact of waste discharged by fish farms through feed and feeding. Rev. Aquacul 3: 19-26.

19. Valdez GF, Diaz F, Re AD, Sierra E (2008) Effect of salinity on physiological energetic of white shrimp Litopenaeus vannamei (Boone). Hidrobiologica 18 105-115.

20. Gong H, Jiang DH, Lightner D, Collins C (2003) Improving osmoregulatory capacity of Litopenaeus vannamei cultured in brackish water through dietary modifications. Aquaculture America, Louisville, Kentucky, USA.

21. Pérez-Velázquez $M$, González-Félix ML, Jaimes Bustamente $F$, MartínezCórdova LR, Trujillo-Villalba DA (2007) Investigation of the effects of salinity and dietary protein level on growth and survival of Pacific white shrimp, Litopenaeus vannamei. J World Aquac Soc 38: 475-485.

22. Gucic M, Jacinto EC, Cerecedo RC, Marie DR, Martínez-Córdova LR (2013) Apparent carbohydrate and lipid digestibility of feeds for whiteleg shrimp, Litopenaeus vannamei (Decapoda: Penaeidae), cultivated at different salinities. Rev Biol Trop 3: 1201-1213.

23. Bückle LF (2006) Osmoregulatory capacity of the shrimp Litopenaeus vanname at different temperatures and salinities, and optimal culture environment. Rev Biol Trop 54: 745-753.

24. Hurtado MA, Racotta IS, Arjona O, Hernández-Rodríguez M, Goytortúa E, et al. (2006) Effect of hypo-and hyper-saline conditions on osmolarity and fatty acid composition of juvenil shrimp Litopenaeus vannamei (Boone, 1931) fed low-and high-HUFA diets. Aquacult Res 37: 1316-1326. 